\title{
Bacterial skin flora variation and in vitro inhibitory activity against Saprolegnia parasitica in brown and rainbow trout
}

\author{
M. T. Carbajal-González, J. M. Fregeneda-Grandes, S. Suárez-Ramos, \\ F. Rodríguez Cadenas, J. M. Aller-Gancedo*
}

Departamento de Sanidad Animal, Facultad de Veterinaria, Universidad de León, 24071 León, Spain

\begin{abstract}
Variations in the number and diversity of bacteria from the skin of brown trout Salmo trutta L. and rainbow trout Oncorhynchus mykiss Walbaum were surveyed from different rivers and fish farms in northern Spain. In addition to determining bacterial populations in skin samples of healthy fish, bacterial populations were determined from skin lesions (of brown trout only) infected with Saprolegnia parasitica, the causal agent of saprolegniosis. Mean bacterial counts from skin lesions of brown trout suffering from saprolegniosis were nearly 1000 times greater than from the skin of uninfected brown and rainbow trout. More than 20 different genera of bacteria were identified, with isolates of Aeromonas and Iodobacter being the predominant genera associated with saprolegniosis lesions. The in vitro inhibitory activity of 72 of these skin isolates was tested against $S$. parasitica using 3 different assays. These included (1) assessing the inhibition by bacteria of colony growth on agar media, (2) the inhibition of colony growth from colonized hemp seeds in liquid media and (3) the inhibition of cyst germination in liquid media. Finally, the fungicidal effect of the 24 most inhibitory bacterial species, and the inhibitory activity of their culture supernatants, was tested in the same way. Isolates identified as Aeromonas piscicola, A. sobria, Pantoea agglomerans and Pseudomonas fluorescens achieved the highest inhibition against $S$. parasitica. Many of these inhibitory isolates were obtained primarily from skin lesions of fish with saprolegniosis. It is suggested that some of these isolates might be useful in the biological control of saprolegniosis.
\end{abstract}

KEY WORDS: Saprolegnia parasitica $\cdot$ Inhibition assays $\cdot$ Bacterial skin flora $\cdot$ Trout

\section{INTRODUCTION}

Saprolegniosis is a disease of freshwater fish caused by Saprolegnia spp., which frequently appears in wild and farmed salmonids. For many years it has been a recurrent problem for brown trout in rivers and hatcheries in north-western Spain, usually emerging in the autumn and winter, coinciding with the spawning period.

Since the banning of malachite green in many countries, control of saprolegniosis has been based on other chemical substances, which, due to their low efficacy, potential toxicity or high cost, are not com- pletely satisfactory. For these reasons, interest in the development of biocontrol measures has increased in the last few years. Bacteria from the skin flora may play a role in development of the disease, and some microorganisms could protect against Saprolegnia parasitica infection on fish (Petersen et al. 1994). Therefore, studying the local flora where the infection is established is likely to yield bacterial isolates potentially useful for biocontrol, as has been done with various other fish and amphibian infections (Spanggaard et al. 2001, Silva et al. 2005, Harris et al. 2006, Goldschmidt-Clermont et al. 2008, Aly et al. 2008, Fjellheim et al. 2010). 
However, the selection of bacteria useful for biocontrol is a laborious task based on in vitro and in vivo tests on a large set of bacteria. In vitro tests, which are used as primary screening, usually comprise several independent tests, which means that they are focused on the demonstration of different bacterial properties. In the case of bacteria for control of Saprolegnia spp., inhibition of mycelium growth and cyst germination (Hatai \& Willoughby 1988, Bly et al. 1997, Hussein \& Hatai 2001, Lategan \& Gibson 2003, Zhang et al. 2008), the ability to kill the organism and the capacity to attach to the mucus of fish are theoretically advantageous features. Studying production of extracellular substances by inhibitory bacteria would add information about their mechanism of action and might make it possible to isolate the inhibitory substance for management of fish health (Lategan et al. 2006). In vivo tests, used as secondary screening, are crucial in determining whether the bacteria are effective in the biocontrol of saprolegniosis (Lategan \& Gibson 2003, Lategan et al. 2004).

The aim of the present work was to determine the in vitro inhibitory activity of bacteria found on the skin of brown and rainbow trout against Saprolegnia parasitica, in order to isolate one or more bacteria potentially useful for the biocontrol of saprolegniosis. We also present information on the inhibitory effects of bacterial supernatants and on variations in the bacterial populations found on the skin of healthy trout and of those infected with $S$. parasitica.

\section{MATERIALS AND METHODS}

\section{Fish and isolation of bacteria}

From April 2006 to January 2007, adult brown trout Salmo trutta L. ( $\mathrm{n}=96 ; 78$ healthy and 18 with saprolegniosis caused by Saprolegnia parasitica) were collected from 3 different sites in the province of León, north-western Spain: (1) the River Porma, which has frequent outbreaks of saprolegniosis caused by $S$. parasitica; (2) the River Omaña, which has no record of the disease; and (3) a hatchery supplied with water from the River Porma, where infected trout are found every year. Healthy specimens were collected at seasonal intervals, and diseased specimens whenever present. Between December 2007 and January 2008, adult healthy rainbow trout Oncorhynchus mykiss Walbaum $(\mathrm{n}=14$ ) were obtained from 3 commercial fish farms located on the Rivers Duerna, Órbigo and Porma, also in the province of León.
All specimens were transported live to the laboratory, killed within $2 \mathrm{~h}$ of collection and their skin surface gently rinsed with sterile distilled water. Samples were obtained from the skin surface of healthy specimens and from cutaneous lesions in those with saprolegniosis. In hatchery brown trout displaying saprolegniosis, samples were also taken from areas of healthy skin. Skin surface samples were obtained by scraping the $2 \mathrm{~cm}^{2}$ area inside the outline of a $16 \mathrm{~mm}$ punch placed on the skin surface, and containing $1 \mathrm{ml}$ phosphate buffered saline (PBS) added as diluent. The resulting mixture was serially diluted in PBS, and $100 \mu \mathrm{l}$ of the appropriate dilutions were spread onto tryptose soya agar (TSA, Cultimed) and sheep blood agar (bioMérieux ${ }^{\circledR}$ ) plates. After aerobic cultivation for $7 \mathrm{~d}$ at $20^{\circ} \mathrm{C}$, the plates were analysed for total counts using dilutions, as far as possible, with between 30 and 300 colonies. The number of colony-forming units (CFU) $\mathrm{cm}^{-2}$ of skin was estimated from the mean of CFU in blood agar and TSA, as the mean counts on these 2 media were similar (ANOVA, p > 0.05).

One colony of the most numerous bacterial types from plates derived from different fish was removed and sub-cultured until pure cultures were obtained. The selected bacterial isolates were stored frozen at $-80^{\circ} \mathrm{C}$ in tryptose soya broth (TSB, Cultimed) with $30 \%$ v/v glycerol.

ANOVA or the Kruskal-Wallis test (K-W) was used to determine whether the differences between means or medians of bacterial counts (after log transformation) were significant $(p<0.05)$. All statistical tests were performed using Epi Info ${ }^{\mathrm{TM}}$ version 3.2.2 software.

\section{Bacterial identification}

Identification of bacterial isolates was carried out first using basic phenotypic methods and then molecular methods. The latter consisted of sequencing the fragment of the 16S rDNA gene amplified by the universal bacterial primers (both from Invitrogen) $27 \mathrm{~F}$ (5'-AGA GTT TGA TC(A:C) TGG CTC AG-3') and 1492R (5'-TAC GG(C:T) TAC CTT GTT ACG ACT T$\left.3^{\prime}\right)$. For identification to species level of isolates identified as belonging to the genus Pseudomonas, a fragment of the 23S rDNA gene was amplified by the primers (both from Invitrogen) fPs16S (5'-ACT GAC ACT GAG GTG CGA AAG CG-3') and rPs23S (5'ACC GTA TGC GCT TCT TCA CTT GAC C-3') (Locatelli et al. 2002).

The sequences were compared with those available in the GenBank database using the BLASTn 
algorithm at http://www.ncbi.nlm.nih.gov/genbank. Representative sequencing outputs are available at http://www.ebi.ac.uk/embl/Access/index.html under the accession numbers FN908434-FN908459.

\section{Inhibition assays with bacteria}

Bacterial and Saprolegnia isolates. A total of 72 bacterial isolates from trout skin, including 61 representatives of the different species identified in this study as well as 11 others from previous isolations in our laboratory (see Table 1), were tested against the Saprolegnia parasitica TRU 8 isolate obtained from a wild brown trout with saprolegniosis (FregenedaGrandes et al. 2000). To test the inhibitory activity of the bacterial isolates, 3 assays were carried out. The first tested the inhibition of hyphal growth on solid media (plate assay), the second and third tested the inhibition of hyphal growth and germination of cysts, respectively, in liquid media (broth assays).

Plate assay. This test was performed in Petri dishes with brain-heart infusion agar (BHI, Cultimed) inoculated with 2 parallel streaks of each bacterium, as described by Hussein \& Hatai (2001). Two plates were prepared per bacterial isolate for each incubation time tested: 3,5 or $7 \mathrm{~d}$ at $20^{\circ} \mathrm{C}$, for a total of 6 plates per isolate. After incubation, a block of agar with Saprolegnia parasitica young hyphal tips, $3 \mathrm{~mm}$ diameter, was placed between the 2 bacterial streaks. The plates were subsequently incubated for $4 \mathrm{~d}$ at $20^{\circ} \mathrm{C}$ and the diameter of the $S$. parasitica colony measured. A negative control plate, without bacterial streaks, was assayed. The diameter reached by the $S$. parasitica colony was used as an indicator of inhibitory activity.

Broth assays (hemp seed test and cyst test). First, the bacterial isolates were inoculated into TSB and incubated at $20^{\circ} \mathrm{C}$ overnight. Following this, a $250 \mu \mathrm{l}$ aliquot of the culture broth was inoculated into $12.5 \mathrm{ml}$ of TSB and incubated until the estimated middle of the exponential growth phase on a rotary orbital shaker (Innova ${ }^{\circledR} 44$, New Brunswick Scientific) at $20^{\circ} \mathrm{C}$ and $200 \mathrm{rpm}$ (the estimate being based on previously established growth curves). The bacteria were pelleted by centrifuging at $1000 \times g$ for $15 \mathrm{~min}$ and resuspended in sterile saline solution. The concentration of bacteria was adjusted (based on the optical density of the cultures) to $2 \times 10^{5}$ bacteria $\mathrm{ml}^{-1}$ for the assays with colonized hemp seeds, and to $4 \times 10^{5}$ bacteria $\mathrm{ml}^{-1}$ for the assays with zoospores, so that the final concentrations of bacteria in the 2 tests were equal. Taking this as the first dilution, five 10fold dilutions of bacterial suspension were prepared.
In parallel, Saprolegnia parasitica was incubated for $3 \mathrm{~d}$ at $20^{\circ} \mathrm{C}$ on glucose peptone (GP) agar (Willoughby \& Pickering 1977). Autoclaved half hemp seeds Cannabis sativa were then placed on the edges of the colony and incubation was continued for another $24 \mathrm{~h}$ at $20^{\circ} \mathrm{C}$. To obtain zoospores, the method described by Fregeneda-Grandes et al. (2000) was used. Briefly, half hemp seeds colonised by hyphae were placed in Petri dishes with filtered autoclaved river water, and incubated for $36 \mathrm{~h}$ at $20^{\circ} \mathrm{C}$. The concentration of zoospores was then estimated using a Hawksley Cristalite BS 748 counting chamber and adjusted to $4 \times 10^{4}$ zoospores $\mathrm{ml}^{-1}$.

For the test with a hemp seed colonized by Saprolegnia parasitica (hemp-seed test), $1 \mathrm{ml}$ of each bacterial dilution, $1 \mathrm{ml}$ of TSB and a half hemp seed colonized by $S$. parasitica were dispensed by duplicate into each well of a 24 -well tissue culture plate (Falcon). Bacteria and $S$. parasitica negative controls were included on each plate. For the assay with the zoospores/cysts of $S$. parasitica (cyst test), the procedure was basically like the hemp-seed test, the only difference being that $0.5 \mathrm{ml}$ of the zoospore suspension was added in place of a colonized hemp seed, and $0.5 \mathrm{ml}$ of each bacterial dilution was used instead of $1 \mathrm{ml}$. Bacteria and S. parasitica zoospore negative controls were also included on each plate. Plates were incubated for $3 \mathrm{~d}$ at $20^{\circ} \mathrm{C}$. Presence/absence of macroscopic or microscopic hyphal growth and germination of cysts was observed throughout the incubation period using a Nikon Diaphot inverted microscope and results were recorded on Day 3.

\section{Assay to determine fungicidal effects}

For this assay we used the 24 bacterial isolates with the highest inhibitory activity, as determined by the previous 3 tests. The bacterial and Saprolegnia parasitica isolates were prepared as for the hemp-seed test in broth assays. Then, $1 \mathrm{ml}$ of each inhibitory bacterial dilution, $1 \mathrm{ml}$ of TSB and a half hemp seed colonized by $S$. parasitica were dispensed by duplicate into each well of a 24 -well plate and incubated at $20^{\circ} \mathrm{C}$. Incubation times of 1,2 or $3 \mathrm{~d}$ were tested. At the end of each period, the hemp seeds in the wells showing no $S$. parasitica growth were removed, washed 3 times with sterile distilled water, placed in a Petri dish with $20 \mathrm{ml}$ of filtered and autoclaved river water containing $2 \times 10^{2} \mathrm{mg}$ streptomycin $\mathrm{l}^{-1}$ and $2 \times$ $10^{5} \mathrm{UI}$ penicillin $\mathrm{l}^{-1}$, and incubated for $20 \mathrm{~d}$ at $20^{\circ} \mathrm{C}$. False positive results due to inhibitory effects of bacteria remaining viable in the mycelium were avoided 
by accepting the results only when there was no growth of bacteria from a sample of the water collected after $24 \mathrm{~h}$. Negative control was achieved by incubating a hemp seed colonized by $S$. parasitica in water both with and without antibiotics. Absence of viability was determined when there was no growth of the mycelium.

\section{Inhibition assays with bacterial culture supernatants}

For these assays the same 24 bacterial isolates used in the test to study fungicidal effects were selected. The method described by Lategan et al. (2006) was used to prepare supernatants. In brief, after the bacteria had been cultivated in tryptone-neutralized peptone broth (TNPB) on a rotary shaker at $180 \mathrm{rpm}$ for $36 \mathrm{~h}$ at $25^{\circ} \mathrm{C}$, they were killed by heating in a water bath for $1 \mathrm{~h}$ at $70^{\circ} \mathrm{C}$. Then the cultures were centrifuged at $15000 \times g$ for 20 min and the supernatant collected. Following this, the supernatants were filtered through a $0.22 \mu \mathrm{m}$ syringe filter (Acro$\operatorname{disc}^{\circledR}$ ) and their $\mathrm{pH}$ was measured and adjusted to 7.0. This supernatant and three 2 -fold serial dilutions in TNPB were tested.

Two broth assays were carried out. The purpose of the first was to investigate the capacity of the supernatants to inhibit hyphal growth (hemp-seed test). In this assay, $2 \mathrm{ml}$ of each supernatant dilution and a half hemp seed colonized by $S$. parasitica were dispensed by duplicate into each well of a 24 -well tissue culture plate. Wells with TNPB instead of the supernatants were included as negative controls. The purpose of the second assay was to investigate the capacity of the supernatants to inhibit cyst germination (cyst test). In this assay, $1 \mathrm{ml}$ of each supernatant dilution and $1 \mathrm{ml}$ of the zoospore suspension (prepared as described under 'Broth assays', above) were added to each well. Wells with TNPB instead of supernatants were included as negative controls. The same incubation times and observation procedures as in 'Broth assays', were completed.

\section{RESULTS}

\section{Skin bacterial counts and identification of bacteria}

The bacterial counts $\mathrm{cm}^{-2}$ of skin after log transformation of each type of sample are shown in Fig. 1. The geometric means of bacterial counts in healthy skin of brown trout with and without saprolegniosis

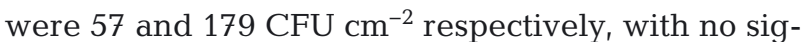
nificant differences between bacterial counts $(\mathrm{K}-\mathrm{W}$, $\mathrm{p}>0.05)$. However, in lesions of saprolegniosis the geometric mean was much higher $\left(57518 \mathrm{CFU} \mathrm{cm}^{-2}\right)$. It was found that, on the skin of healthy brown trout, the mean bacterial counts in each season (from 23 to $168 \mathrm{CFU} \mathrm{\textrm {cm } ^ { - 2 }}$ ) and at each sampling point (from 22 to $\left.90 \mathrm{CFU} \mathrm{cm}{ }^{-2}\right)$ were significantly different $(\mathrm{K}-\mathrm{W}, \mathrm{p}<$ 0.001 and ANOVA, $p=0.0029$ respectively). A considerable difference (ANOVA, $p<0.005$ ) was also found between the mean bacterial counts in fish from the 3 rainbow trout fish farms, which varied from 12 to $834 \mathrm{CFU} \mathrm{cm}^{-2}$ (ANOVA, $\mathrm{p}<0.005$ ).

In total, 137 bacteria were selected (119 from healthy and diseased brown trout and 18 from healthy rainbow trout) and 23 bacterial genera and 28 species were identified (Table 1 ). The identification to genus level was achieved by sequencing the 16S rRNA gene in all the isolates in which this method was used. However, using the phenotypic tests, only $56.2 \%$ of isolates were identified to genus level. Using molecular methods, identification to species level was achieved in $59.4 \%$ of the isolates. The results from phenotypic tests and from molecular identification were identical with respect to genera identified.

Species most frequently isolated from the skin of healthy brown trout were Iodobacter sp., Deefgea rivuli and Yersinia kristensenii (with all Yersinia isolates being obtained in summer); from the healthy skin of brown trout with saprolegniosis, Iodobacter sp. and D. rivuli; from saprolegniosis lesions on these individuals, Iodobacter sp., Aeromonas sobria and Aeromonas sp.; and from the skin of healthy rainbow trout, Chryseobacterium sp., Pseudomonas fluorescens and Staphylococcus sp., each species predominating at a different fish farm (Table 1).

\section{Inhibition assays with bacteria}

Plate assays. Because the highest difference in the inhibitory action upon mycelium growth among bacteria tested was observed when Saprolegnia parasitica was inoculated onto plates with bacterial cultures previously grown for $7 \mathrm{~d}$, it was this incubation period against which degree of inhibition was measured. On the negative control plates the colony grew to $4 \mathrm{~cm}$ in diameter (Fig. 2). Presence of inhibitory activity was determined when the $S$. parasitica colony reached a diameter of $2.5 \mathrm{~cm}$ or less, and was observed in all 72 isolates. Inhibitory activity was then grouped into 3 inhibition levels depending on 

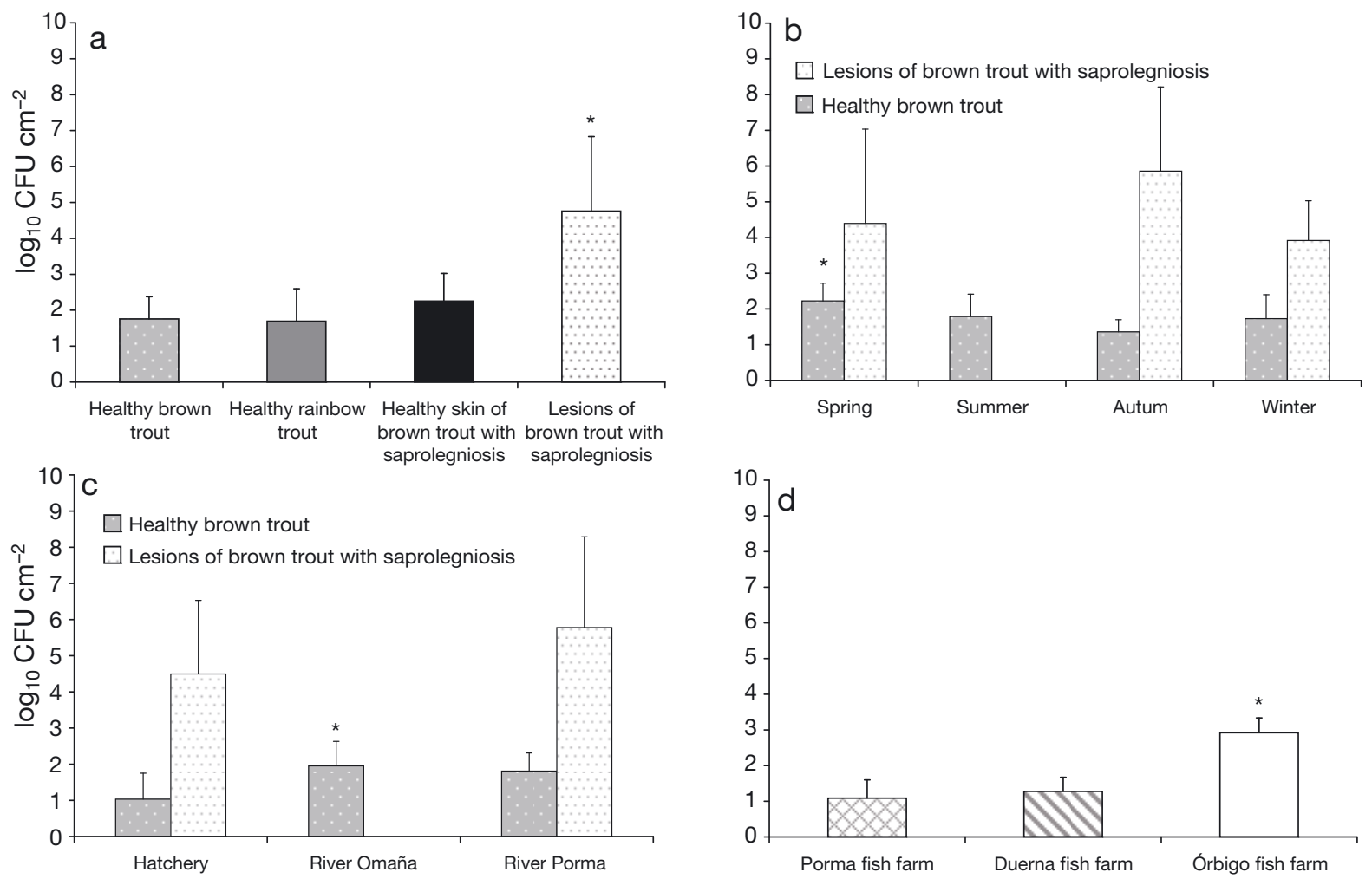

Fig. 1. Bacterial plate counts (mean $\mathrm{CFU} \mathrm{cm} \mathrm{cm}^{-2}+\mathrm{SD}$ ) from skin or lesions of brown trout Salmo trutta and rainbow trout Oncorhynchus mykiss. (a) Total; (b) by season; (c) by sampling location; (d) from 3 rainbow trout fish farms. No trout with saprolegniosis were found either in summer or in the river Omaña. Asterisk: significantly higher mean $(p<0.05)$ than the mean of the other samples; (b) and (c) only in healthy trout

the diameter reached by the $S$. parasitica colony (Tables 2 \& 3).

Broth assays. For the hemp-seed test, the absence of macroscopic hyphal growth after $3 \mathrm{~d}$ of incubation was used to indicate inhibitory activity (Fig. 2). It was found that 41 out of the 72 bacterial isolates $(56.9 \%)$ tested exhibited this activity at any dilution. The minimum number of bacteria added to the wells necessary for the inhibition of $S$. parasitica was used to establish 3 levels of inhibitory activity. The results of this assay are shown in Tables $2 \& 3$.

For the cyst test, it was observed that none of the 72 bacterial isolates inhibited cyst germination, but that the mycelium growth was inversely proportional to the concentration of bacteria added to the wells. Therefore, absence of macroscopic growth at any dilution after $3 \mathrm{~d}$ of incubation was considered as inhibitory activity, and it was found in 52 out of the 72 isolates $(72.2 \%)$. Depending on the minimal concentration of bacteria necessary for this effect, 3 levels of inhibition were fixed. The results of this assay are shown in Tables $2 \& 3$.

Fungicidal effect of the bacteria. Fifteen of the 24 bacteria species tested proved to be lethal for Sapro- legnia parasitica under any of the conditions assayed (Table 3). A small and atrophied brown mycelium was observed after $20 \mathrm{~d}$ of incubation in water, in contrast to the control plates and plates with the nonfungicidal bacteria, in which the mycelium grew and produced zoospores. The bacteria caused the lethal effect on $S$. parasitica only up to the second dilution $\left(2 \times 10^{4}\right.$ bacteria per well), and with at least $2 \mathrm{~d}$ of incubation together at $20^{\circ} \mathrm{C}$.

Most inhibitory isolates. The isolates with high inhibitory activity in the plate assay, capable of inhibiting Saprolegnia parasitica with a lower concentration of bacteria in the broth assays and also with fungicidal effect, were considered the best (Table 3). These isolates belonged to the species Aeromonas piscicola, A. sobria, Pantoea agglomerans and Pseudomonas fluorescens, many of them $(66.6 \%)$ obtained from saprolegniosis lesions.

Inhibition assays with the bacterial culture supernatants. In the broth assay with colonized hemp seeds, it was observed that 19 of the 24 bacterial supernatants tested showed inhibition of Saprolegnia parasitica mycelium growth after $3 \mathrm{~d}$ of incubation. Total inhibition was observed at the first dilu- 
Table 1. Taxonomic identification of bacteria isolated from skin of brown trout Salmo trutta and rainbow trout Oncorhynchus mykiss, and of bacterial isolates used in the in vitro inhibition assays against Saprolegnia parasitica

\begin{tabular}{|c|c|c|c|c|c|c|}
\hline \multirow[t]{2}{*}{ Bacteria } & \multirow[t]{2}{*}{$\begin{array}{l}\text { Healthy } \\
\text { brown trout }\end{array}$} & \multicolumn{2}{|c|}{$\begin{array}{l}\text { Brown trout with } \\
\text { saprolegniosis }\end{array}$} & \multirow{2}{*}{$\begin{array}{l}\text { Healthy } \\
\text { rainbow } \\
\text { trout }\end{array}$} & \multirow[t]{2}{*}{$\begin{array}{c}\text { Total } \\
\text { isolates }\end{array}$} & \multirow{2}{*}{$\begin{array}{c}\text { Isolates used } \\
\text { in the } \\
\text { inhibition assays }\end{array}$} \\
\hline & & Healthy skin & Lesions & & & \\
\hline Achromobacter xylosoxidans & 2 & 0 & 0 & 0 & 2 & 1 \\
\hline Acinetobacter lwoffii & 0 & 0 & 1 & 0 & 1 & 1 \\
\hline Acinetobacter johnsonii ${ }^{\mathrm{a}}$ & - & - & - & - & - & 2 \\
\hline Acinetobacter sp. & 1 & 0 & 1 & 0 & 2 & 0 \\
\hline Aeromonas piscicola & 0 & 0 & 1 & 0 & 1 & 1 \\
\hline Aeromonas popoffii & 0 & 0 & 3 & 0 & 3 & 2 \\
\hline Aeromonas salmonicida & 0 & 0 & 3 & 0 & 3 & 1 \\
\hline Aeromonas salmonicida $^{\mathrm{a}}$ & - & - & - & - & - & 1 \\
\hline Aeromonas sobria & 2 & 1 & 10 & 0 & 13 & 9 \\
\hline Aeromonas sp. & 0 & 1 & 6 & 0 & 7 & 0 \\
\hline Brevundimonas nasdae & 1 & 0 & 0 & 0 & 1 & 0 \\
\hline Carnobacterium maltaromaticum & 1 & 1 & 1 & 0 & 3 & 1 \\
\hline Chryseobacterium sp. & 3 & 0 & 0 & 6 & 9 & 3 \\
\hline Deefgea rivuli & 6 & 2 & 0 & 0 & 8 & 3 \\
\hline Flavobacterium succinicans & 1 & 0 & 0 & 0 & 1 & 0 \\
\hline Flavobacterium sp. & 1 & 1 & 1 & 0 & 3 & 2 \\
\hline Flavobacterium sp. ${ }^{\mathrm{a}}$ & - & - & - & - & - & 1 \\
\hline Frigoribacterium sp. & 0 & 0 & 0 & 1 & 1 & 1 \\
\hline Gram-negative rods & 0 & 0 & 0 & 1 & 1 & 0 \\
\hline Gram-positive rods & 0 & 0 & 0 & 1 & 1 & 0 \\
\hline Iodobacter fluviatilis & 2 & 0 & 1 & 0 & 3 & 1 \\
\hline Iodobacter sp. & 9 & 2 & 11 & 0 & 22 & 6 \\
\hline Iodobacter sp. ${ }^{\mathrm{a}}$ & - & - & - & - & - & 1 \\
\hline Janthinobacterium lividum & 2 & 0 & 0 & 0 & 2 & 1 \\
\hline Janthinobacterium sp. & 1 & 0 & 0 & 0 & 1 & 1 \\
\hline Kocuria rhizophila & 2 & 0 & 0 & 0 & 2 & 1 \\
\hline Kurthia zopfii & 0 & 0 & 1 & 0 & 1 & 1 \\
\hline Microbacterium foliorum & 1 & 0 & 0 & 0 & 1 & 1 \\
\hline Microbacterium hydrocarbonoxydans & 1 & 0 & 0 & 0 & 1 & 1 \\
\hline Microbacterium phyllosphaerae & 1 & 0 & 0 & 0 & 1 & 0 \\
\hline Microbacterium sp. & 1 & 0 & 0 & 0 & 1 & 1 \\
\hline Moraxella osloensis & 0 & 0 & 0 & 1 & 1 & 1 \\
\hline Pantoea agglomerans & 3 & 0 & 0 & 0 & 3 & 3 \\
\hline Plantibacter agrosticola & 0 & 1 & 0 & 0 & 1 & 1 \\
\hline Pseudomonas fluorescens & 1 & 1 & 4 & 4 & 10 & 5 \\
\hline Pseudomonas fluorescens ${ }^{\text {a }}$ & - & - & - & - & - & 1 \\
\hline Rhodococcus fascians & 1 & 0 & 0 & 0 & 1 & 1 \\
\hline Rhodococcus fascians ${ }^{\mathrm{a}}$ & - & - & - & - & - & 1 \\
\hline Rhodococcus sp. & 2 & 1 & 0 & 1 & 4 & 1 \\
\hline Serratia fonticola & 2 & 0 & 0 & 0 & 2 & 1 \\
\hline Staphylococcus aureus ${ }^{\mathrm{a}}$ & - & - & - & - & - & 1 \\
\hline Staphylococcus equorum ${ }^{\mathrm{a}}$ & - & - & - & - & - & 3 \\
\hline Staphylococcus pasteuri & 1 & 1 & 0 & 0 & 2 & 1 \\
\hline Staphylococcus sp. & 3 & 1 & 1 & 3 & 8 & 2 \\
\hline Xanthomonas retroflexus & 1 & 0 & 0 & 0 & 1 & 1 \\
\hline Yersinia enterocolitica & 2 & 0 & 0 & 0 & 2 & 2 \\
\hline Yersinia intermedia & 2 & 0 & 0 & 0 & 2 & 1 \\
\hline Yersinia kristensenii & 5 & 0 & 0 & 0 & 5 & 2 \\
\hline Total & 61 & 13 & 45 & 18 & 137 & 72 \\
\hline
\end{tabular}

tion, and was achieved by only 10 bacterial isolates. This was considered high inhibition. If mycelium growth was reduced in comparison to the control, but not inhibited totally, it was considered low inhibition (Table 3).
When bacterial supernatants were used in the cyst test, the growth of mycelia from the cysts, but not their germination, was inhibited in 20 of the 24 isolates tested. After $3 \mathrm{~d}$ of incubation, 14 of these isolates showed high inhibition at first dilution (Table 3). 

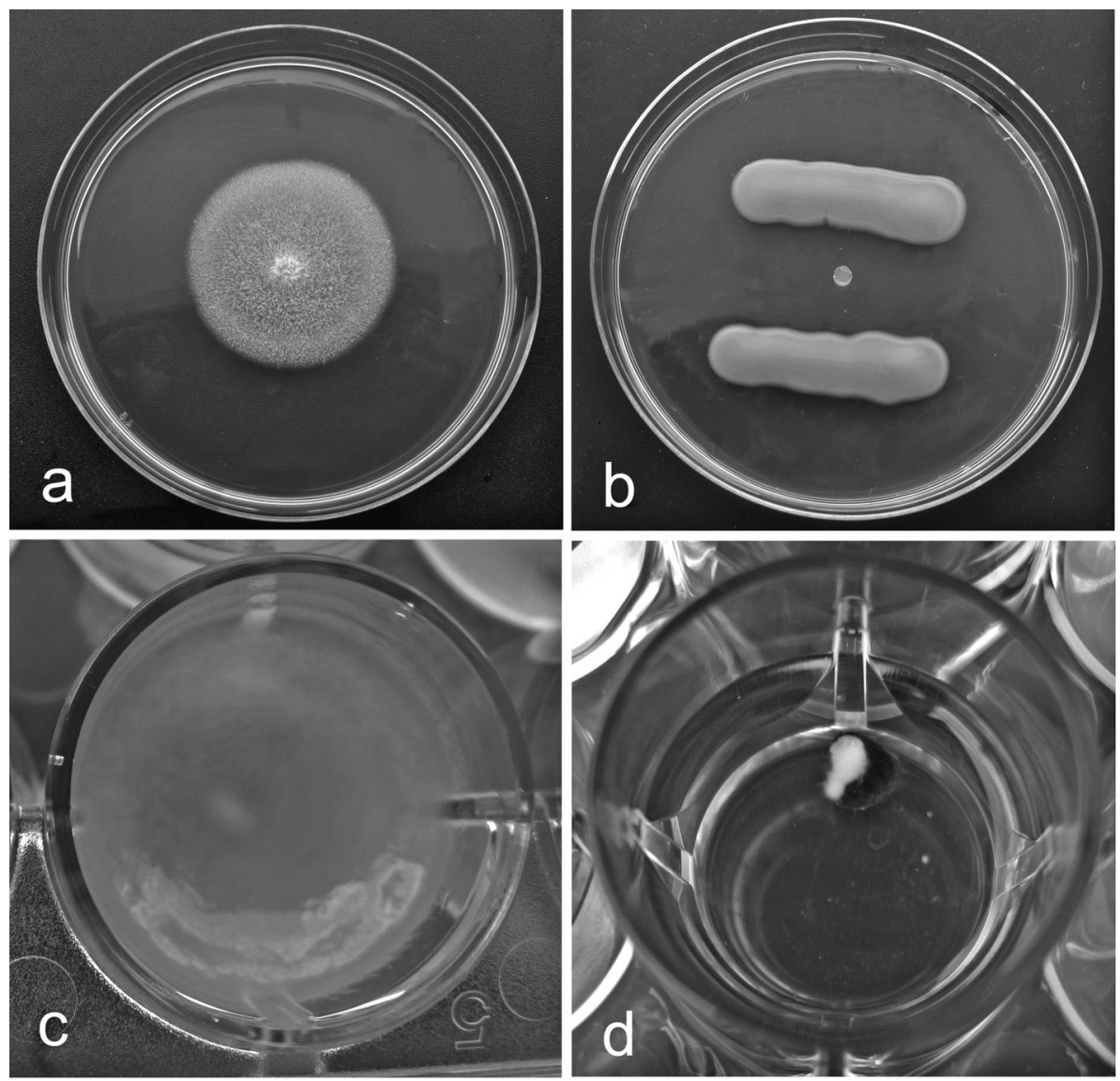

Fig. 2. In vitro inhibition assays of Saprolegnia parasitica with bacteria on solid media and in 24 -well tissue culture plates with colonized hemp seed and liquid media. (a) Control plate (solid medium) with S. parasitica after $4 \mathrm{~d}$ at $20^{\circ} \mathrm{C}$. (b) High inhibition of $S$. parasitica (solid medium) caused by a Xanthomonas retroflexus isolate after $4 \mathrm{~d}$ at $20^{\circ} \mathrm{C}$, with bacteria previously grown for $7 \mathrm{~d}$. (c) Control well (liquid medium) with $S$. parasitica after $3 \mathrm{~d}$ at $20^{\circ} \mathrm{C}$. (d) High inhibition of $S$. parasitica (liquid medium) caused by an Aeromonas sobria isolate after $3 \mathrm{~d}$ at $20^{\circ} \mathrm{C}$

Table 2. Degree of inhibition of Saprolegnia parasitica achieved by 72 bacterial isolates in assays on BHI agar (plate assays), in liquid media with hemp seed colonized by $S$. parasitica (hemp seed test) and in liquid media with cysts of $S$. parasitica (cyst test)

\begin{tabular}{|c|c|c|c|c|}
\hline \multirow[t]{2}{*}{ Test } & \multirow{2}{*}{$\begin{array}{l}\text { Degree of } \\
\text { inhibition }\end{array}$} & \multirow[t]{2}{*}{ Indicator of degree of inhibition } & \multicolumn{2}{|c|}{ acterial isolates with inhibitory activity } \\
\hline & & & No. & $\begin{array}{l}\text { Total } \\
(\% \text { of total tested })\end{array}$ \\
\hline \multirow[t]{4}{*}{ Plate assay } & & Diameter of $S$. parasitica colony after 4 d at $20^{\circ} \mathrm{C}^{\text {a }}$ & & $72(100 \%)$ \\
\hline & Low & $1.5-2.5 \mathrm{~cm}$ & 13 & \\
\hline & Medium & $0.7-1.5 \mathrm{~cm}$ & 12 & \\
\hline & High & $<0.7 \mathrm{~cm}$ & 47 & \\
\hline \multirow[t]{4}{*}{ Hemp seed test } & & $\begin{array}{l}\text { Total inhibition of macroscopic mycelium growth } \\
\text { after } 3 \mathrm{~d} \text { at } 20^{\circ} \mathrm{C}\end{array}$ & & $41(56.9 \%)$ \\
\hline & Low & with $2 \times 10^{5}$ bacteria & 10 & \\
\hline & Medium & with $2 \times 10^{4}$ bacteria & 5 & \\
\hline & High & with $\leq 2 \times 10^{3}$ bacteria & 26 & \\
\hline \multirow[t]{4}{*}{ Cyst test } & & $\begin{array}{l}\text { Total inhibition of macroscopic mycelium growth } \\
\text { after } 3 \mathrm{~d} \text { at } 20^{\circ} \mathrm{C}\end{array}$ & & $52(72.2 \%)$ \\
\hline & Low & with $2 \times 10^{5}$ bacteria & 16 & \\
\hline & Medium & with $2 \times 10^{4}$ to $2 \times 10^{3}$ bacteria & 9 & \\
\hline & High & with $\leq 2 \times 10^{2}$ bacteria & 27 & \\
\hline
\end{tabular}


Table 3. Results of all in vitro tests performed with 24 bacterial isolates with high inhibitory activity against Saprolegnia parasitica. HBT: healthy brown trout; BTSH: brown trout with saprolegniosis, healthy skin; BTSL: brown trout with saprolegniosis, lesions; HRT: healthy rainbow trout; bracketed nos.: minimum number of bacteria causing total inhibition of macroscopic mycelium growth. Supernatants inhibition: High (total absence of macroscopic mycelium growth achieved with first dilution after $3 \mathrm{~d}$ of incubation at $20^{\circ} \mathrm{C}$ ); Low (partial inhibition of macroscopic mycelium growth achieved with first dilution

\begin{tabular}{|c|c|c|c|c|c|c|c|c|}
\hline \multirow[t]{3}{*}{ Species } & \multirow{3}{*}{$\begin{array}{c}\text { Bacterial } \\
\text { isolate }\end{array}$} & \multirow[t]{3}{*}{ Origin } & \multirow{3}{*}{$\begin{array}{l}\text { Plate } \\
\text { assays }\end{array}$} & \multicolumn{2}{|c|}{ Broth assays } & \multirow{3}{*}{$\begin{array}{c}\text { Fungicidal } \\
\text { effect }\end{array}$} & \multirow{2}{*}{\multicolumn{2}{|c|}{$\begin{array}{c}\text { Inhibitory activity } \\
\text { of supernatants }\end{array}$}} \\
\hline & & & & Hemp seed test & Cyst test & & & \\
\hline & & & & & & & $\begin{array}{l}\text { Hemp seed } \\
\text { test }\end{array}$ & $\begin{array}{l}\text { Cyst } \\
\text { test }\end{array}$ \\
\hline Aeromonas piscicola $^{\mathrm{a}}$ & LE 21 & BTSL & High & High (200) & High (20) & Yes & High & High \\
\hline A. popoffii & LE 65 & BTSL & High & High (20) & High (20) & No & High & High \\
\hline A. popoffii & LE 69 & BTSL & High & High (200) & High (200) & Yes & High & High \\
\hline A. salmonicida & LE 9 & BTSL & High & High (20) & High (20) & No & High & High \\
\hline A. salmonicida & LE 99 & BTSL & High & High (20) & High (20) & No & High & High \\
\hline A. sobria & LE 17 & BTSL & High & High (20) & High (20) & No & High & Low \\
\hline A. sobria & LE 51 & HBT & High & High (2000) & High (20) & Yes & High & High \\
\hline A. sobria & LE 68 & BTSL & High & High (20) & High (20) & No & High & High \\
\hline A. sobria ${ }^{\mathrm{a}}$ & LE 74 & BTSL & High & High (200) & High (20) & Yes & Low & High \\
\hline A. sobria & LE 76 & BTSL & High & High (20) & High (20) & No & High & High \\
\hline A. sobria & LE 100 & BTSL & High & High (20) & High (20) & No & Low & High \\
\hline A. sobria & LE 104 & $\mathrm{BTSH}$ & High & High (20) & High (20) & Yes & High & High \\
\hline Pantoea agglomerans & LE 35 & HBT & High & High (2000) & High (200) & Yes & No & No \\
\hline P. agglomerans & LE 36 & HBT & High & High (2000) & High (200) & Yes & No & No \\
\hline P. agglomerans ${ }^{\mathrm{a}}$ & LE 37 & HBT & High & High (200) & High (20) & Yes & Low & Low \\
\hline Pseudomonas fluorescens & LE 89 & $\mathrm{HBT}$ & High & High (2000) & High (20) & Yes & Low & High \\
\hline P. fluorescens ${ }^{\mathrm{a}}$ & LE 98 & BTSL & High & High (200) & High (20) & Yes & Low & Low \\
\hline P. fluorescens ${ }^{\mathrm{a}}$ & LE 122 & BTSL & High & High (200) & High (20) & Yes & Low & High \\
\hline P. fluorescens & LE 141 & HRT & High & High (200) & High (20) & No & Low & Low \\
\hline P. fluorescens ${ }^{\mathrm{a}}$ & LE 143 & HRT & High & High (200) & High (20) & Yes & Low & Low \\
\hline Serratia fonticola & LE 52 & HBT & High & High (2000) & High (200) & Yes & No & No \\
\hline Xanthomonas retroflexus & LE 38 & $\mathrm{HBT}$ & High & High (2000) & High (200) & No & Low & High \\
\hline Yersinia kristensenii & LE 54 & HBT & High & High (2000) & High (200) & Yes & No & No \\
\hline Y. kristensenii & LE 58 & HBT & High & High (2000) & High (200) & Yes & No & Low \\
\hline
\end{tabular}

\section{DISCUSSION}

In the present study, it was observed that the bacterial skin flora of brown trout is dependent on factors such as season and habitat. Furthermore, the predominant bacterial genera and species of this flora were identified and some of them shown to have in vitro inhibitory capability against Saprolegnia parasitica. Thus, these are candidates for further study in the biocontrol of saprolegniosis.

Making comparisons among studies involving bacterial counts is complex, as several factors are involved. Among these are the method of taking the sample from the fish and the culture media used (Spanggaard et al. 2000, Nedoluha et al. 2001, Huber et al. 2004, Romero \& Navarrete 2006). Austin (2006) reported that, generally, bacterial populations on the skin of fish range from $10^{2}$ to $10^{4}$ bacteria $\mathrm{cm}^{-2}$. In the present study, the aerobicbacteria counts on the healthy skin of brown trout and rainbow trout were markedly below those found by González et al. (1999) in the same species of fish from the province of León using the skin scraping method. This disagreement of findings may be caused by differences in sampling method, given that these investigators transported the fish dead in plastic boxes to the laboratory within $6 \mathrm{~h}$ of collection, and in the culture media used. In the current study, high variability was found in bacterial counts, as well as significant differences among bacterial mean counts on the skin of healthy brown trout during different seasons. Al-Harbi \& Uddin (2004) found seasonal differences in the intestinal flora of tilapia and related them to oscillations in the water temperature, higher bacterial concentrations being more likely at increased water temperature. However, the flora of fish can also be influenced by other environmental factors, which may explain why, in the present study, bacterial counts were highest in spring and lowest in autumn, when 
the first trout with saprolegniosis usually appear in the province of León. This fact, in addition to the fact that the very highest counts were found in specimens from the river Omaña, which has no record of outbreaks of the disease, might indicate that microflora on the skin are related to the presence of saprolegniosis.

In fish farms, disinfectants are often added to the water to control a range of organisms. This may have an adverse effect on bacterial flora of the skin, and may well explain the fact that the lowest bacterial counts were observed in hatchery brown trout. Moreover, the highest counts in rainbow trout were obtained from the Órbigo fish farm, where chemical treatments were not used.

With regard to the bacterial species found on the skin of our trout specimens, a greater diversity of species was observed on healthy skin than in lesions. Iodobacter was the genus most frequently isolated from the skin of healthy brown trout, and Aeromonas from saprolegniosis lesions. In contrast to the report of González et al. (1999), we found Aeromonas sp. to be sparse on healthy trout, probably because of the differences in sampling methods used.

Among the 4 inhibition assays performed in the present study, the assays on solid media seemed to be less useful than the others in judging the extent of the inhibitory activity of the bacterial isolates, because on BHI agar all of them inhibited growth of Saprolegnia parasitica to different degrees, with about two-thirds of the isolates inhibiting growth completely. Moreover, bacteria that were inhibitory in broth assays also showed considerable inhibition on solid media, but the opposite was not true. Hussein \& Hatai (2001) observed inhibition with only 5 out of 47 strains using $\mathrm{HI}$ agar, but afterwards they demonstrated that the inhibition was increased by using BHI. However, Zhang et al. (2008) observed a low inhibitory activity of bacteria against pathogenic members of Saprolegnia on BHI. These authors demonstrated that the composition of the culture media could affect the inhibitory activity of Serratia marcescens against Saprolegnia spp. and that the highest inhibition was obtained on potato dextrose agar followed by BHI.

In liquid media, it was observed that none of the isolates tested inhibited the germination of cysts, but they did reduce the growth of the resulting mycelium. The inhibition of cyst germination has already been studied by other investigators with contradictory results (Bly et al. 1997, Lategan \& Gibson 2003, Zhang et al. 2008). In the present study Saprolegnia parasitica mycelium growth from cysts was inhibited at lower concentrations of the bacteria than were hyphae from colonized hemp seed. This may be due to the longer time necessary for hyphae to grow from the cysts than for the hemp seed, where the mycelium was already present.

The bacterial isolates with the strongest inhibitory activity against Saprolegnia parasitica in the assays with bacterial cells belonged to the genera Aeromonas, Pantoea and Pseudomonas, many of them being isolated from lesions of saprolegniosis. Hatai \& Willoughby (1988) and Hussein \& Hatai (2001) likewise isolated Aeromonas and Pseudomonas with inhibitory properties from saprolegniosis lesions. The latter investigators stated that the presence of inhibitory bacteria in saprolegniosis lesions may be relevant, given the fact that microbial interactions in the lesions are a possible reason for the spontaneous recovery of some trout with saprolegniosis. In contrast, Petersen et al. (1994) found unidentified bacteria antagonistic to $S$. parasitica in the skin mucus of healthy rainbow trout, but not in those with saprolegniosis.

The in vitro inhibitory activity of Pseudomonas fluorescens and Serratia spp. against Saprolegnia spp. has been described by several authors (Hatai \& Willoughby 1988, Bly et al. 1997, Zhang et al. 2008). In the present study, most of the isolates identified as $P$. fluorescens and one belonging to the genus Serratia showed a fairly strong antagonistic activity.

It was also observed that, in agreement with Lategan et al. (2006), some bacteria were able to kill Saprolegnia parasitica. This is an interesting finding. Not only did these bacteria not cause infection, but they could also cure incipient lesions.

The mechanism involved in anti-Saprolegnia bacterial activity is unknown, but the fact that both the vegetative and cyst stages were harmed could have significant implications for in vivo control of Saprolegnia spp. infections in fish farms and hatcheries (Lategan \& Gibson 2003). In the present study most of the bacterial supernatants inhibited the in vitro growth of Saprolegnia parasitica, which suggests that a substance secreted into the medium causes or participates in the inhibitory effect of the bacteria. Furthermore, higher sensitivity to the bacterial supernatants of mycelia grown from cysts than of those grown from hemp seed was demonstrated, as was also observed by Zhang et al. (2008). The strongest inhibitory activity was shown by the supernatants of bacteria belonging to the genus Aeromonas, whereas those produced by Enterobacteriaceae did not show this inhibitory effect - although, because these bacteria are fungicidal, other mecha- 
nisms might be implicated for this property. Lategan \& Gibson (2003) found a bacteriocin-like substance secreted by a strain of Aeromonas media, which had inhibitory activity against Saprolegnia sp. and other pathogens; its main component was identified to be indole (Lategan et al. 2006). Zhang et al. (2008) also found that the supernatant of a Serratia marcescens strain was inhibitory against Saprolegnia sp. However, other investigators found no inhibition to be caused by bacterial supernatants (Bly et al. 1997, Hussein \& Hatai 2001), and speculated that other mechanisms might be implicated, such as competition for iron, or capacity to degrade cellulose or to liquefy gelatine.

In the present work, bacteria from both healthy skin and saprolegniosis lesions in trout were isolated. Some of them, mostly Aeromonas and Pseudomonas isolates, showed strong inhibitory activity against Saprolegnia parasitica in the various in vitro assays performed. These bacteria are good candidates for use in the biological control of saprolegniosis (by oral route or added to water), but further work is necessary to determine the degree of danger of these bacteria to fish (given the fact that some inhibitory isolates belong to species that cause diseases in fish) and other characteristics, such as their capacity to adhere to the skin mucus of fish.

Acknowledgements. This work formed part of the research project AGL2006-03374 financed by the Spanish Ministry of Education and Science (Ministerio de Educación y Ciencia) and the European Regional Development Fund (ERDF). M.T.C.G. was supported by a fellowship from the Educational Bureau of the Regional Government of Castile and León (Junta de Castilla y León, Consejería de Educación), co-financed by the European Social Fund. We thank the Local Environmental Service in León of the Regional Government of Castile and León (Servicio Territorial de Medio Ambiente de León, Junta de Castilla y León) for helping us in the collection of brown trout from the rivers and from the Vegas del Condado hatchery. We also thank B. Austin, D. Austin and M. Barker, of Heriot-Watt University, Edinburgh, for their help in the sequencing of the 16S rDNA of some of the bacteria.

\section{LITERATURE CITED}

Al-Harbi AH, Uddin MN (2004) Seasonal variation in the intestinal bacterial flora of hybrid tilapia (Oreochromis niloticus $\times$ Oreochromis aureus) cultured in earthen ponds in Saudi Arabia. Aquaculture 229:37-44

Aly SM, Abd-El-Rahman AM, John G, Mohamed MF (2008) Characterization of some bacteria isolated from Oreochromis niloticus and their potential use as probiotics. Aquaculture 277:1-6

Austin B (2006) The bacterial microflora of fish, revised. Sci World J 6:931-945
Bly JE, Quiniou SMA, Lawson LA, Clem LM (1997) Inhibition of Saprolegnia pathogenic for fish by Pseudomonas fluorescens. J Fish Dis 20:35-40

Fjellheim AJ, Klinkenberg G, Skjermo J, Aasen IM, Vadstein $O$ (2010) Selection of candidate probionts by two different screening strategies from Atlantic cod (Gadus morhua L.) larvae. Vet Microbiol 144:153-159

- Fregeneda-Grandes JM, Fernández-Díez M, Aller-Gancedo JM (2000) Ultrastructural analysis of Saprolegnia secondary zoospore cyst ornamentation from infected wild brown trout, Salmo trutta L., and river water indicates two distinct morphotypes amongst long-spined isolates. J Fish Dis 23:147-160

Goldschmidt-Clermont E, Wahli T, Frey J, Burr SE (2008) Identification of bacteria from the normal flora of perch, Perca fluviatilis L., and evaluation of their inhibitory potential towards Aeromonas species. J Fish Dis 31: 353-359

González CJ, López-Díaz TM, García-López ML, Prieto M, Otero A (1999) Bacterial microflora of wild brown trout (Salmo trutta), wild pike (Esox lucius), and aquacultured rainbow trout (Oncorhynchus mykiss). J Food Prot 62: 1270-1277

Harris NR, James TY, Lauer A, Simon NA, Patel A (2006) Amphibian pathogen Batrachochytrium dendrobatidis is inhibited by the cutaneous bacteria of amphibian species. EcoHealth 3:53-56

Hatai K, Willoughby LG (1988) Saprolegnia parasitica from rainbow trout inhibited by the bacterium Pseudomonas fluorescens. Bull Eur Assoc Fish Pathol 8:27-29

- Huber I, Spanggaard B, Appel KF, Rossen L, Nielsen T, Gram L (2004) Phylogenetic analysis and in situ identification of the intestinal microbial community of rainbow trout (Oncorhynchus mykiss, Walbaum). J Appl Microbiol 96:117-132

Hussein MA, Hatai K (2001) In vitro inhibition of Saprolegnia by bacteria isolated from lesions of salmonids with saprolegniasis. Fish Pathol 36:73-78

Lategan MJ, Gibson LF (2003) Antagonistic activity of Aeromonas media strain A199 against Saprolegnia sp., an opportunistic pathogen of the eel, Anguilla australis Richardson. J Fish Dis 26:147-153

> Lategan MJ, Torpy FR, Gibson LF (2004) Biocontrol of saprolegniosis in silver perch Bidyanus bidyanus (Mitchell) by Aeromonas media strain A199. Aquaculture 235:77-88

- Lategan MJ, Booth W, Shimmon R, Gibson LF (2006) An inhibitory substance produced by Aeromonas media A199, an aquatic probiotic. Aquaculture 254:115-124

> Locatelli L, Tarnawski S, Hamelin J, Rossi P, Aragno M, Fromin N (2002) Specific PCR amplification for the genus Pseudomonas targeting the 3 ' half of $16 \mathrm{~S}$ rDNA and the whole 16S-23S rDNA spacer. Syst Appl Microbiol 25: 220-227

- Nedoluha PC, Owens S, Russek-Cohen E, Westhoff D (2001) Effect of sampling method on the representative recovery of microorganisms from the surfaces of aquacultured finfish. J Food Prot 64:1515-1520

Petersen A, Jegstrup I, Olson LW (1994) Screening for bacteria antagonistic to Saprolegnia parasitica with BASF Pluronic Polyol F-127. In: Mueller GJ (ed) Salmon saprolegniasis. US Department of Energy, Bonneville Power Administration, Portland, OR, p 149-160

Romero J, Navarrete P (2006) 16S rDNA-based analysis of dominant bacterial populations associated with early life 
stages of coho salmon (Oncorhynchus kisutch). Microb Ecol 51:422-430

Silva FCP, Brito MFG, Farias LM, Nicoli JR (2005) Composition and antagonistic activity of the indigenous intestinal microbiota of Prochilodus argenteus Agassiz. J Fish Biol 67:1686-1698

Spanggaard B, Huber I, Nielsen J, Nielsen T, Appel KF, Gram L (2000) The microflora of rainbow trout intestine: a comparison of traditional and molecular identification. Aquaculture 182:1-15

Spanggaard B, Huber I, Nielsen J, Sick EB and others (2001)

Editorial responsibility: David Bruno,

Aberdeen, UK
The probiotic potential against vibriosis of the indigenous microflora of rainbow trout. Environ Microbiol 3: 755-765

Willoughby LG, Pickering AD (1977) Viable saprolegniaceae spores on the epidermis of the salmonid fish Salmo trutta and Salvelinus alpinus. Trans Br Mycol Soc 68: 91-95

Zhang SJ, Yang XL, Li D, Li Y, Gao P (2008) Screening of antagonistic bacterium strain against saprolegniosis and the preliminary study of in vitro antagonistic activity. Acta Hydrobiol Sin 32:301-307

Submitted: December 27, 2010; Accepted: June 29, 2011

Proofs received from author(s): August 21, 2011 